\title{
Effects of integrated reporting on the cost of capital and analysts' forecasts errors: A study of Johannesburg Stock Exchange listed mining firms
}

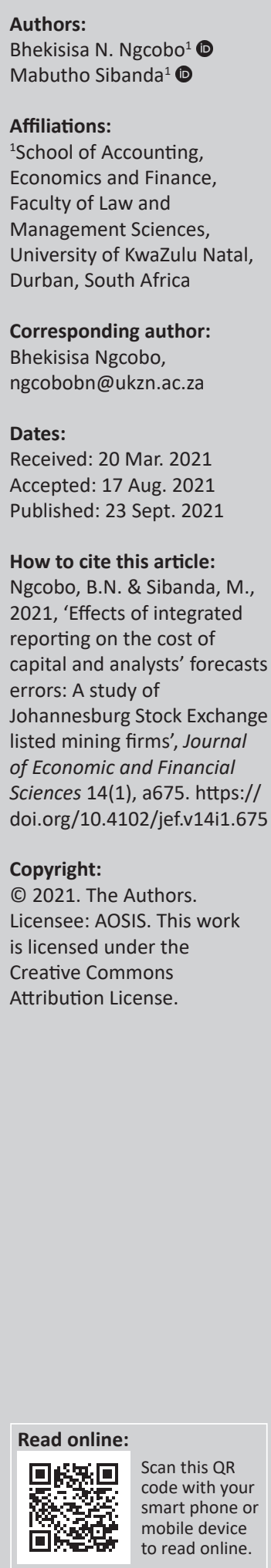

Orientation: Integrated reporting (IR) has gained traction over the last decade. Although IR became mandatory for all firms listed on Johannesburg Stock Exchange (JSE) in 2010, the International Integrated Reporting Council (IIRC) issued the IR framework in December 2013.

Research Purpose: The study seeks to investigate the effects of IR on the cost of equity capital and analysts' forecast errors for the mining firms listed on JSE.

Motivation for the study: A large part of empirical evidence highlights benefits of IR; however, some studies still find no link between the quality of integrated reports and economic benefits for the reporting firm. It is against this backdrop that the study investigates effects of integrated reports on the cost of equity capital and analysts' forecast errors.

Research approach, design and method: We use a quantitative research design to test effects of IR on the cost of equity capital and analysts' forecast errors. We study used a panel regression to analyse relationship amongst IR, cost of equity capital and analysts' forecast errors.

Main findings: The study found a significant negative relationship between IR scores and cost of equity and analysts' forecast errors.

Practical or managerial application: The findings of the study could incentivise managers in other jurisdictions where IR is not mandatory. Furthermore, findings may contribute to the existing discourse on firm-based benefits related to the quality of IR.

Contribution or value addition: The study contributes to the body of knowledge with regard to possible benefits associated with compliance with the IR reporting framework.

Keywords: integrated reporting (IR); voluntary disclosures; analysts' forecast error; cost of equity capital; stock exchange.

\section{Introduction}

The better part of the last decade has seen integrated reporting (IR) gaining momentum, and its proponents have hailed its advent as the most significant recent development in the corporate reporting space. However, some critics perceive of it as simply another box ticking exercise, because of its bias towards providers of financial capital (Flower 2015). Amongst the early adopters, South Africa was the trailblazer in executing IR for all listed companies on the Johannesburg Stock Exchange (JSE) (Zhou, Simnett \& Green 2017). The International Integrated Reporting Council (IIRC 2013) defines IR as:

[C]oncise communication about how an organization's strategy, governance, performance, and prospects, in the context of its external environment, lead to the creation of value over the short, medium and long term. (p. 7)

The Council adds that IR is the foundation for significant change in the manner in which information is reported to stakeholders. Although IR is supposed to benefit all stakeholders (business partners, local communities, customers, suppliers, legislators, regulators and employees), its primary aim is to explain to investors how the firm creates value over time (IIRC 2013). Given that it is a relatively new concept, it has attracted considerable research interest, particularly with regard to the evidence-based benefits ascribed to compliance with the IR framework.

The JSE is one of the top 20 stock exchanges in the world and the largest in Africa by market capitalisation at the end of year 2020 (JSE 2021). The mining sector was selected because of 
its dominance in South Africa's political, social and economic landscape (MineralsSA 2018). In 2017, this sector employed 464667 people and contributed R312 billion to GDP (MineralsSA 2018). The listed mining firms are, therefore, a reasonable representation of the South African economy. It is against this backdrop that this study investigates the effect of IR on the cost of equity capital (COE) and analysts' forecast errors (FCERROR) for the JSE listed mining firms.

\section{Review of literature}

This study is premised on the agency theory. The theory seeks to identify and solve the agency problem between owners and managers of the firm (Jensen \& Meckling 1976; Panda \& Leepsa 2017; Ross 1973). For example, the managers may have good strategic plans about investments that would yield good returns in the end and in the process decide to adjust the dividend policy. However, if the shareholders do not have such information, the strategic plan could result in shareholders disposing their shares if they were expecting more dividends. Some of the ways to minimise agency problem (Adhariani \& De Villiers 2019; García Sánchez \& Noguera Gámez 2017; Vitolla, Raimo \& Rubino 2020a) include a firm's desire to meet the needs of providers of financial capital. To this end, the reporting firm provides strategic information on the business model and its ability to seize opportunities and mitigate risks and explain the creation of value over time.

The inclusiveness nature of IR and its inclination towards providers of capital make agency theory relevant to the study (IIRC 2013, Flower 2015, Vitolla et al. 2020b). Theories provide the basis upon which reporting and disclosures are developed (Urquiza et al. 2010). The agency theory acknowledges that there is an agency problem between principals (shareholders) and agents (executives) (Shapiro 2005) and seeks to mitigate this problem and its associated costs. By addressing agency problems, firms are likely to experience a reduction in estimation risk and information asymmetry (Diamond \& Verrecchia 1991; Verrecchia 2001; Vitolla et al. 2019; Zhou et al. 2017). As posited by Serafeim (2015), firms that adopt strategies to reduce information asymmetries improve their opportunities of attracting funds from the capital market. Such improvement is attributed to the reduction of agency costs. The integrated thinking culture in itself forces the firm to think big and strategically in their daily operations. The conciseness, connectivity, future orientation, risk mitigation and opportunistic approach of IR are possible contributing factors that could enable a firm attract funding from the capital market.

Empirical evidence from previous literature suggests that there is a negative relationship between the high-quality disclosures and FCERROR (Barth, Kasznik \& McNichols 2001; Bradshaw, Miller \& Serafeim 2009; Dhaliwal et al. 2012; Flores et al. 2019; Lehavy, Li \& Merkley 2011; Zhou et al. 2017). Similarly, studies by Zhou et al. (2017), Vitolla et al.
(2019) and Flores et al. (2019) find a link between high quality disclosures and reduction in FCERROR. The evidence from previous studies by Dhaliwal et al. (2012), Zhou et al. (2017) and Bernardi and Stark (2018) suggests that financial analysts do not only use financial information when predicting future cash flows, but they also rely on the non-financial information presented in the form of voluntary disclosures. The findings highlight the relevance of non-financial information to the analysts. Provision of more complete data would thus reduce FCERROR (Dhaliwal et al. 2011). Moreover, as highlighted by Serafeim (2015), analysts are likely to adopt a favourable view of organisations that provide more information.

Some studies attribute reduction of COE to the quality of non-financial disclosures (Chang et al. 2017; El Ghoul et al. 2011; Hail 2002; Suto \& Takehara 2018; Vitolla et al. 2019; Zhou et al. 2017). These studies suggest benefits such as improved forecasts of cash flows, improvement of investor loyalty and mitigation of agency costs. Previous studies suggest a theoretical link between the extent to which disclosures affect non-diversifiable risk and COE (Botosan 1997; Johnson 2020; Mazzotta \& Veltri 2014; Petrova et al. 2012; Poshakwale \& Courtis 2005). Similarly, Lambert, Leuz and Verrecchia (2007) suggest that the assessed level of risk associated with future cash flows can be influenced by accounting information. As an improved and concise disclosure mechanism, IR is expected to help firms reduce information asymmetry and estimation risk. Information that is more relevant will reduce the risk premium. Serafeim (2015) argues that data asymmetry between an organisation's executives and external financial specialists creates uncertainty. The bigger the potential information gap between management and investors, the more probable it is that investors will require a higher rate of return to compensate for the bigger risk. The impact of information asymmetry is greater for long-term investors as their returns depend on future cash flows and sustainability accounting. Because IR takes cognisance of the long-term outlook, it makes provision for information about long-term growth prospects. This is crucial for investors who wish to plant seeds (financial capital) with the aim of obtaining a bountiful harvest (returns). According to Serafeim (2015), firms that provide more information on social, environmental and governance issues tend to outperform (in financial capital terms) those that do not produce or produce fewer Environmental, Social and Governance (ESG) reports. This suggests that firms with superior ESG activities have easier access to investors' financial capital. Furthermore, it is posited by Serafeim (2015) that organisations that reveal more ESG data enjoy a lower cost of capital and improved access to funds.

Previous research also shows that disclosures can limit the non-diversifiable risk, which would result in a decrease in the cost of capital. When a firm produces transparent disclosures, investors tend to show greater support and willingness to invest, which will improve its liquidity. In the 
same vein, Zhou et al. (2017) investigated the impact of integrated reports' level of compliance with the IR framework on the implied cost of capital and FCERROR dispersion for all firms listed on JSE. The researchers developed a scorecard to assess the level of alignment with the framework. The study found a significant negative relationship between integrated reports' level of alignment with the framework and the implied cost of capital and FCERROR.

Despite the theoretical inclination towards negative relationship between the quality of disclosures and COE, it is not uncommon to encounter literature that suggests the opposite. Richardson and Welker (2001) found that the greater extent of disclosures leads to an increase in COE. Dirman (2019) and Eriandani, Narsa and Irwanto (2019) found a positive relationship between the non-financial disclosures and COE, which suggests the undesirable effect of voluntary disclosures. Moreover, Mulyati (2017) found information included in disclosures to be irrelevant to the decisions of investors, suggesting no effect of the cost of capital. Furthermore, Ellis, Fee and Thomas (2012) suggest that managers are faced with a trade-off between benefits and risk disclosures of exposing the firm to the competitors who could capitalise on disclosed information. This potential exposure to competitors is referred to as proprietary costs (Ellis et al. 2012; Guidry \& Patten 2012; Peters \& Romi 2014). More disclosures could also work against the reporting firm by revealing risks to the market participants. For example, Baboukardos and Rimmel (2016) investigated the impact of adopting IR and found that firms' net asset value declined after the adoption of IR. This was attributed to more reliable risks disclosures about financial sustainability. One can thus deduce that it is possible for the COE to increase because of adopting IR, depending on the nature of the new information and how the markets react to it.

\section{Methodology \\ Data}

The study aims to assess the impact of IR on the cost of equity and financial FCERROR. Therefore, a quantitative design is appropriate. The annual integrated reports were obtained from firms' websites. Board size and board independence were sourced from McGregor BFA Library database. We collect socially responsible investment (SRI) data from the FTSE/JSE responsible investment index, which is available on JSE website. The rest of metrics (firm size, market-to-book ratio, leverage, beta and COE, FCERROR and volatility) was sourced from the Bloomberg and McGregor BFA Library databases. We then arranged dependent and independent variables in a panel data format, from 2013 to 2018 . The year 2013 is a good starting point because the international IR framework was issued in December 2013 (IIRC 2013). According to the category list from JSE website, there were 58 mining firms listed on JSE (2015). Nevertheless, for the purpose of the study, some firms were omitted because they either did not publish integrated reports or did not adopt the IR framework. Therefore, total treatment securities group covered 37 JSE listed mining firms over a period of 6 years (2013-2018) listed on JSE. However, in some instances, the data required for the panel regression model were not available from Bloomberg and McGregor BFA Library databases. Thus, in the final analysis, there were 166 observations to test the effect of IR on the cost of equity. This was followed by 218 observations for assessing the cost of equity before and after IR framework. Lastly, 58 observations were recorded for the analysts forecast errors.

\section{Model specification}

Similar to related studies by Dhaliwal et al. (2011), Zhou et al. (2017), we adapt panel data regression to assess the relationship between the variables (independent and dependent). In order to customise the model to the South African mining industry, we include sustainability reporting and corporate governance. All firms listed on JSE are also expected to publish sustainability and corporate governance reports. We estimate multivariate equations to achieve the study's objectives. To this end, the relationship between the cost of equity and IR is estimated as follows:

$$
\begin{aligned}
& \operatorname{COE}_{i t}=\beta_{0}+\beta_{1} \operatorname{IRSCORE}_{i t}+\beta_{2} \text { BRDSIZE }_{i, t}+ \\
& \beta_{3} I N D E P_{i t}+\beta_{4} \operatorname{SRI}_{i t}+\beta_{5} L E V_{i t}+\beta_{6} \text { BETA }_{i t}+ \\
& \beta_{7} \operatorname{SIZE}_{i t}+\beta_{8} M B_{i t}+\varepsilon_{i t}
\end{aligned}
$$

The regression model as adapted from Dhaliwal et al. (2011).

In order to probe the possible effect of IR on the cost of equity, firms with high integrated scores (30 and above) were selected. For the purpose of the study, firms with high scores were considered to be in full compliance with the IIRC framework (IIRC 2013). Although IR became mandatory for all JSE listed firms, the IR framework was only pronounced in December 2013. It is on this basis, firms would be expected to produce quality and comparable integrated reports after the pronouncement of IR framework. Hence, we regress balance panel data for years 2007-2012 and 2013-2018. The effect of once off events, such as global financial crisis, is mitigated by the use of longitudinal data. We create a dummy variable for periods before and after (BAIR), and it is coded as zero (0) and one (1), respectively. Accordingly, the following regression is estimated:

$$
\begin{aligned}
& C O E_{i t}=\beta_{0}+\beta_{1} \text { BAIR }_{i t}+\beta_{2} \text { BRDSIZE }_{i, t}+\beta_{3} I N D E P_{i t}+ \\
& \beta_{4} S R I_{i t}+\beta_{5} L E V_{i t}+\beta_{6} B E T A_{i t}+\beta_{7} \operatorname{SIZE}_{i t}+\beta_{8} M B_{i t}+\varepsilon_{i t}
\end{aligned}
$$

Adapted from Dhaliwal et al. (2012), the following regression was used in order to determine the effect of IR on FCERROR amongst JSE listed mining firms. We estimate the following regression:

$$
\begin{aligned}
& \text { FCERROR }_{i t}=\beta_{0}+\beta_{1} \text { IRSCORE }_{i t}+\beta_{2} \text { BRDSIZE }_{i, t}+ \\
& \beta_{3} I N D E P_{i t}+\beta_{4} S_{i t}+\beta_{5} L_{i t}+\beta_{6} \text { BETA }_{i t}+\beta_{7} \text { SIZE }_{i t}+\text { [Eqn 3] } \\
& \beta_{8} M B_{i t}+\beta_{9} \text { VOL }_{i t}+\varepsilon_{i t}
\end{aligned}
$$


where:

- $\mathrm{COE}=$ Cost of equity capital

- IR_SCORE = Total score assigned to integrated reports

- BAIR = Dummy variable for periods before and after IR Framework

- BRDSIZE $=$ Total number of executive and non-executive directors

- INDEP = Ratio of non-executive directors to the total number of directors

- SRI = Socially Responsible Investment

- SIZE = Natural logarithm of firm's total assets

- $\mathrm{BETA}=$ Market beta at the end of the month after financial year-end

- $\mathrm{LEV}=$ Debt to assets at the end of the financial year

- $\mathrm{MB}=$ Market-to-book ratio at the end of the year

- FCERROR = Difference between actual earnings and estimated earnings

- $\mathrm{VOL}=$ Variance of returns over the financial year period

All the above variables are briefly discussed in 'cost of equity capital, Analysts' forecast errors, integrated reports, control variables' sections.

\section{Cost of equity capital}

There are different views when it comes to selecting best proxy for the cost of capital. This can be attributed to possible errors because of measurement assumptions (Barth et al. 2017; Vitolla et al. 2019; Zhou et al. 2017). Zhou et al. (2017) used the PEG model as a proxy for the cost of capital, whereas Barth et al. (2017) used a mean of proxies found in the literature by (Claus \& Thomas 2001; Easton, Domachowske \& Rosenberg 2004; Gebhardt, Lee \& Swaminathan 2001; Ohlson \& Juettner-Nauroth 2005). We obtained inputs for the cost of equity from Bloomberg and McGregor BFA Library research domains. However, because of the limited access profile, we only reviewed results from Capital Asset Pricing Model and Gordon Dividend Valuation models. Ward and Muller (2012), Karp and Van Vuuren (2017), Cox and Britten (2019) argued against the appropriateness of using CAPM and Fama-French Three Factor models, citing shortcomings such as incomplete market proxies, volatility of market and restriction of market liquidity. Moyo and Mache (2018), however, investigated variances between financial models in relation to CAPM. Moyo and Mache (2018) found that Gordon Dividend and Ohlson and Juettner-Nauroth (2005) models yielded results, which were close to that of CAPM. In order to mitigate biasness and the effect of measurement errors, our final proxy for the cost of equity is the average of CAPM and Gordon Dividend Valuation models.

\section{Analysts' forecast errors}

As stated in the study by Zhou et al. (2017), FCERROR refer to the difference between the average estimates made by analysts over a period of 12 months and actual earnings. Bissessur and Veenman (2016) attribute analysts forecast errors to uncertainty about firms' prospects. Bakker et al. (2020) found a significant negative relationship between mandatory IR and analysts forecast errors. Such findings suggest that financial analysts do not only rely on conventional financial statements but also consider nonfinancial disclosures. Therefore, if financial analysts consider IR, the actual earnings should not be too far from estimated earnings. We collected data for FCERROR from Bloomberg and McGregor BFA Library databases. Adapted from Bissessur and Veenman (2016), Zhou et al. (2017) and Bakker et al. (2020), the formula for analysts forecast errors is presented as follows:

FCERROR $=\frac{\text { Actual EPS }- \text { Estimated EPS }}{\text { Actual EPS }}$

[Eqn 4]

where:

- FCERROR = Analysts' forecast errors

- $\mathrm{EPS}=$ Earnings per share

\section{Integrated reports}

Pistoni, Songini and Bavagnoli (2018) suggest that the quality of integrated reports is assessed by including contents elements, assurance and reliability. Similar to Dhaliwal et al. (2011) study on voluntary disclosures, a negative coefficient was expected between the IR score and the dependent variables. Whilst there is no available database for IR scores, the study adopted the same approach from other related studies by Zhou et al. (2017) and Vitolla et al. (2019) in which the $<\mathrm{IR}>$ framework content elements are used as an assessment tool. Barth et al. (2017) used the proprietary data from EY excellence awards data, whilst Cosma, Soana and Venturelli (2018) used the events study methodology in which they assessed the quality of integrated reports on the basis of awards ceremonies. Owing to the limited access to proprietary data, a self-constructed scorecard was developed.

Although there is an inherent biasness in the self-constructed assessment tool, this factor was mitigated by the adoption of IIRC content elements. The scoring of integrated reports was thoroughly scrutinised against each point of the content elements. Moreover, in terms of robustness and consistency, firms with high scores were compared with those who were top performers on the performance awards by Ernst \& Young and Institute for Chartered Secretaries. Consistent with the IR Framework, firms with higher scores also featured prominently in EY Excellence Awards. The data for the regression models were prepared in three phases. Firstly, the annual IR scores for each company were documented in a spreadsheet. Similar to Lee and Yeo (2016), Dube (2017), a scorecard was developed to record the quality levels of integrated reports. To this end, we make use of spreadsheet tool to assess and record each company's integrated reports based on the elements of IR Framework (IIRC 2013). The selected dimensions and their respective scores were (1) Organisational overview and external environment (5), (2) Governance (5), (3) Business model (10), (4) Risks and opportunities (3), (5) Strategy and resource allocation (5), (6) 
Performance (5) and (7) Outlook (5). Therefore, the minimum and maximum scores for each firm were 0 and 38, respectively. Zero is a theoretical score, for instance, in which the purported integrated report does not meet any requirement of the content elements of the framework. Each point of content elements met by the reporting firm was awarded one. The total scorecard is shown in Appendix 1. The annual integrated reports were obtained from the companies' websites.

Secondly, the annual COE and FCERROR data were obtained from the Bloomberg and McGregor BFA Library databases. The data in respect of the control variables were also obtained from the Bloomberg terminal. All data pertaining to the first two phases were then captured in an excel spreadsheet. The third and final step is an analysis of data through STATA 15 statistical software.

\section{Control variables}

The previous literature shows that certain variables are correlated to the COE and analyst' forecast errors (Barth et al. 2017; Conway 2019; Dhaliwal et al. 2011, 2012; Zhou et al. 2017). Likewise, we control the board size (BRDSIZE), which is measured as a total number of both executive and non-executive directors. Alabdullah, Nor and Ries (2018), Merendino and Melville (2019) found a direct relationship between the size of the board and financial performance. This could filter down to reduction of cost of capital because of investor confidence. Independence (INDEP) is measured as a percentage number of non-executive directors over the total number of directors. Non-executive and executive directors carry legitimacy, integrity and stewardship roles (Ciftci et al. 2019; Dzingai \& Fakoya 2017; Krechovská \& Procházková 2014). King Code of Corporate Governance suggests that independence leads to objectivity in execution of mandated duties (IoDSA 2020). Firm size (SIZE) is measured as a natural logarithm of the total assets, because total assets is widely used as a proxy for firm size. Botosan and Plumlee (2005) found an inverse correlation between the size of the firm and the COE. Socially responsible investment is a variable for sustainability reporting. The JSE FTSE SRI makes data available, pertaining to the firms that met the minimum ESG rating requirements (FTSE 2019). Constituents are those firms that have complied with minimum ESG rating requirements in a period. Zero (0) is coded where the firm is not included in the constituency list, whereas one (1) refers to being a constituent.

Beta measures the security risk in relation to the overall market risk (Sharpe 1964). The beta is included in the model because of its positive impact on the COE (Khlif, Samaha \& Soliman 2019). The market-to-book (MB) value could influence the COE (Fama \& French 1993). Previous studies by Flores et al. (2019) and Vitolla et al. (2019) suggest possible influence of financial leverage on the cost of capital and FCERROR. We, therefore, control the effect of leverage (LEV). Lastly, Dichev and Tang (2009) highlight the possible impact of volatility of earnings on analysts' predictions. It is on this basis that we use control for volatility (VOL) in estimating FCERROR.

\section{Results and discussion}

\section{Descriptive statistics}

In order to examine the link between dependent variables (cost of equity and FCERROR), we begin with descriptive statistical analysis. Descriptive statistical analysis provides the number of observations, mean, standard deviation, minimum and maximum values. The mean refers to the average of values whilst the standard deviation (s.d.) measures the dispersion of variables from the mean. The descriptive analyses of the variables are shown in Tables 1 and 2. The average cost of equity (COE) for all firms included in a sample is 0.111 . Meanwhile, the average of the cost of equity (untabulated) in the pre- and post-analyses is 0.122 . This is consistent with the previous literature. The average COE found in Zhou et al. (2017) is 0.13 , whilst that of Vitolla et al. (2020b) is 0.113. Integrated reporting score (IRSCORE) has a mean value of 23162 out of maximum 38, which indicates that most firms performed relatively well in their IR. The mean value of analysts' forecast error (FCERROR) is 0.0127, which reflects that, on an average, the analysts' estimates are not far from actual earnings. In the absence of earnings management and other factors, the results support the notion that IR improves the availability of the relevant information required by analysts in order to predict firms' earnings.

TABLE 1: Descriptive statistics: Cost of equity.

\begin{tabular}{lccccc}
\hline Variable & Observations & Mean & SD & Minimum & Maximum \\
\hline COE & 166 & 0.111 & 0.031 & 0.024 & 0.203 \\
IR_SCORE & 166 & 23.162 & 8.798 & 6 & 37 \\
BRDSIZE & 166 & 9.542 & 2.616 & 4 & 17 \\
INDEP & 166 & 0.739 & 0.101 & 0.400 & 0.857 \\
SRI & 166 & 0.368 & 0.484 & 0 & 1 \\
LEV & 166 & 1.459 & 1.391 & -2.42 & 12.09 \\
BETA & 166 & 1.075 & 1.023 & -0.429 & 3.982 \\
SIZE & 166 & 14.22 & 4.828 & -0.0131 & 21.355 \\
MB & 166 & 1.103 & 1.562 & -0.36 & 17.142 \\
\hline
\end{tabular}

COE, cost of equity; SD, standard deviation; IR_SCORE, integrated reporting; BRDSIZE, board size; INDEP, independence of directors; SRI, sustainability reporting index; LEV, financial leverage; BETA, market beta; SIZE, firm size; MB, market-to-book value.

TABLE 2: Descriptive statistics: Analysts' forecast error.

\begin{tabular}{lccccc}
\hline Variable & Observations & Mean & SD & Minimum & Maximum \\
\hline FCERROR & 58 & 0.0127 & 0.118 & -0.556 & 0.504 \\
IR_SCORE & 58 & 27.172 & 8.705 & 6 & 37 \\
BRDSIZE & 58 & 10.500 & 2.486 & 5 & 17 \\
INDEP & 58 & 0.721 & 0.114 & 0.444 & 0.857 \\
SRI & 58 & 0.482 & 0.504 & 0 & 1 \\
LEV & 58 & 1.930 & 0.594 & 1.095 & 3.730 \\
BETA & 58 & -9.454 & 25.858 & -116.862 & 15.46 \\
SIZE & 58 & 9.140 & 1.928 & 2.061 & 12.939 \\
MB & 58 & 1.269 & 2.2098 & 0.951 & 17.142 \\
VOL & 58 & 0.537 & 0.214 & 0.237 & 1.336 \\
\hline
\end{tabular}

FCERROR, analysts' forecast errors; SD, standard deviation; IR_SCORE, integrated reporting score; BRDSIZE, board size; INDEP, independence of directors; SRI, sustainability reporting index; LEV, financial leverage; BETA, market beta; SIZE, firm size; MB, market-to-book value; VOL, volatility of earnings. 


\section{Correlation}

The pairwise correlation is presented in Tables 3 and 4 .

Table 3 shows the results of the pairwise correlation coefficient between COE and the independent variables (IR_SCORE, BRDSIZE, INDEP, SRI, LEV, BETA, SIZE and MB). As expected, there is a negative relationship between quality of IR and cost of equity. However, the Pearson correlation between the cost of equity and the IR score is insignificant. This is in contrast with results found by Vitolla et al. (2019). There is a significant correlation between the COE and INDEP and LEV variables. This seems to suggest that board's independence and firm's leverage contribute to reducing the COE. The remainder of the control variables does not have significant correlation with the COE. The correlation results (untabulated) for the pre- and post-IR framework also show similar patterns.

Table 4 presents correlation results of the analysts' forecast error (FCERROR). Similar to Dhaliwal et al. (2012) and Zhou et al. (2017), the FCERROR has a significant ( $p=0.0249)$ negative correlation with IR_SCORE. The same is true for BRDSIZE, INDEP and SRI. Notably, the volatility of security (VOL) has significant $(p=0.01)$ negative correlation with analysts forecast errors. This highlights a significant impact of volatility on financial FCERROR (Dichev \& Tang 2009; Zhou et al. 2017). The remainder of the control variables (LEV, BETA, SIZE and $\mathrm{MB}$ ) has insignificant correlation with the FCERROR.

Prior to regression analysis, we performed the diagnostics test to check for the normal assumptions of linear regression
(GURU 2019). To this end, we tested for multicolinearity (VIF factor), heteroscedasticity (Breusch - Pagan), normality (PRKurtosis) and serial correlation (Breusch Godfrey test). The results (untabulated) primarily show that the normal assumptions of regression are met. After performing diagnostic tests, we run the Hausman test to arrive at an informed decision in selecting the appropriate model between fixed and random effects. The Hausman test provides guidance on the choice between fixed effects and random effects regression models (Hausman \& Taylor 1981). The Hausman test results (not included in tables) show that the random effect model was appropriate for the first two models (COE), whilst the fixed effect was selected for the third model (FCERROR).

\section{Regression analysis}

Panel regressions were used to test the effect of the independent variables (IR_SCORE, BRDSIZE, INDEP, SRI, SIZE, LEV, MB and BETA) on the dependent variables (Cost of Equity and Analysts' forecast error). Tables 5, 6 and 7 present results from regression analyses.

Table 5 shows the results of random effects of generalised least square (GLS) regression processed with Stata 15 statistical software. Similar to previous studies by Zhou et al. (2017) and Vitolla et al. (2019), there is a negative coefficient and significant $(p=0.043)$ negative relation between the cost of equity and the IR score (IR_SCORE). The results suggest that as the firm improves IR, the cost of equity tends to decrease. As indicated in the literature

TABLE 3: Correlation: Cost of equity and independent variables.

\begin{tabular}{|c|c|c|c|c|c|c|c|c|c|}
\hline Variable & COE & IR_SCORE & BRDSIZE & INDEP & SRI & LEV & BETA & SIZE & MB \\
\hline$\overline{\mathrm{COE}}$ & 1.000 & - & - & - & - & - & - & - & - \\
\hline IR_SCORE & -0.085 & 1.000 & - & - & - & - & - & - & - \\
\hline BRDSIZE & $0.034 * *$ & $0.533 * *$ & 1.000 & - & - & - & - & - & - \\
\hline INDEP & $0.078 * *$ & $0.293 * *$ & $0.283^{* *}$ & 1.000 & - & - & - & - & - \\
\hline SRI & -0.041 & $0.680 * *$ & $0.418^{* *}$ & $0.256^{*}$ & 1.000 & - & - & - & - \\
\hline LEV & $-0.007 * *$ & -0.044 & -0.119 & 0.065 & 0.049 & 1.000 & - & - & - \\
\hline BETA & 0.090 & 0.080 & -0.248 & 0.350 & 0.168 & 0.050 & 1.0000 & - & - \\
\hline SIZE & -0.0707 & $0.619 * *$ & $0.569 * *$ & $0.458 *$ & $0.492^{* *}$ & $-0.185 * *$ & $0.029 *$ & 1.0000 & - \\
\hline MB & -0.049 & -0.005 & -0.098 & -0.066 & 0.091 & -0.180 & -0.146 & -0.001 & 1.000 \\
\hline
\end{tabular}

IR_SCORE, integrated reporting score; BRDSIZE, board size; INDEP, independence of directors; SRI, sustainability reporting index; LEV, financial leverage; BETA, market beta; SIZE, firm size; MB, market-to-book value; COE, cost of equity capital.

*, Significant at the 0.1 level (two tailed); **, significant at the 0.05 level (two tailed).

TABLE 4: Correlation: Analysts' forecast error and independent variables.

\begin{tabular}{|c|c|c|c|c|c|c|c|c|c|}
\hline Variable & FCERRORRRRRRR & IR_SCORE & BRDSIZE & INDEP & SRI & LEV & BETA & SIZE & MB \\
\hline FCERROR & 1.0000 & - & - & - & - & - & - & - & - \\
\hline IR_SCORE & $-0.2944 * *$ & 1.0000 & - & - & - & - & - & - & - \\
\hline BRDSIZE & $-0.410 * *$ & $0.347 * *$ & 1.000 & - & - & - & - & - & - \\
\hline INDEP & $-0.378 * *$ & $0.235^{*}$ & $0.297 * *$ & 1.000 & - & - & - & - & - \\
\hline SRI & $-0.201 * *$ & $0.504 * *$ & $0.363 * *$ & 0.090 & 1.000 & - & - & - & - \\
\hline LEV & -0.1209 & $0.273 * *$ & 0.047 & $0.526 * *$ & $0.271 * *$ & 1.0000 & - & - & - \\
\hline BETA & 0.0543 & -0.133 & -0.013 & 0.121 & 0.054 & 0.0594 & 1.0000 & - & - \\
\hline SIZE & -0.0374 & $0.417 * *$ & $0.549 * *$ & 0.041 & $0.394 * *$ & -0.0786 & -0.1524 & 1.0000 & - \\
\hline $\mathrm{MB}$ & -0.010 & -0.196 & $-0.296 * *$ & -0.153 & -0.0254 & -0.0830 & 0.0453 & $-0.399 * *$ & 1.0000 \\
\hline VOL & $-0.523 * * *$ & $-0.355^{*}$ & $-0.318 * *$ & -0.215 & -0.305 & $0.1293 * *$ & 0.221 & $0.395 * *$ & 1.0000 \\
\hline
\end{tabular}

FCERROR, analysts' forecast errors; IR SCORE, integrated reporting score; BRDSIZE, board size; INDEP, independence of directors; SRI, sustainability reporting index; LEV, financial leverage; BETA, market beta; SIZE, firm size; MB, market-to-book value; VOL, volatility of earnings.

*, Significant at the 0.1 level (two tailed); **, significant at the 0.05 level (two tailed); ***, significant at the 0.001 level (two tailed). 
review section, some of the costs of equity can be attributed to the agency problem. In this context, the integrated report is linked to reducing risks related to agency costs. BRDSIZE and BETA are also observed to be negatively associated with COE although not significant. The other variables, which significantly affect cost of equity, are SIZE $(p=0.001)$ and $\operatorname{LEV}(p=0.000)$.

Table 6 presents results of pre- and post-IR regression analysis. Compared to the first regression (Table 5), the results in Table 6 are significant and more pronounced. Table 5 includes 37 mining firms that produced IR reports, whereas Table 6 only uses a sample of firms with integrated scores above 30 . These firms with high scores were included in a longitudinal panel over 6 year's pre- and post-IR framework. The coefficient of 'BAIR' represents before and after IR framework. The 'BAIR' coefficient is both negative and significant $(p=0.000)$. Similar to related studies, the results confirm that the adoption of IR may assist a reporting firm in reducing the cost of equity (Johnson 2020; Vitolla et al. 2019; Zhou et al. 2017). Sustainability reporting (SRI) also has a significant $(p=0.10)$ negative relationship with cost of equity. This indicates that firms who meet the ESG disclosure requirements may realise reduced cost of equity. Such findings highlight the importance of sustainability reporting, which could support the importance of sustainability accounting in IR framework

\begin{tabular}{lcccccc}
\multicolumn{7}{l}{ TABLE 5: Regression results: Cost of equity. } \\
\hline Variables & Coefficient & Robust s.e. & $\mathbf{Z}$ & $\boldsymbol{p}$ & $\mathbf{9 5 \%}$ conf. & Interval \\
\hline IR_SCORE & -0.0004 & 0.020 & -2.02 & $0.043^{* *}$ & -0.0008332 & -0.001 \\
BRDSIZE & -0.001 & 0.001 & -0.24 & 0.813 & -0.001833 & 0.001 \\
INDEP & 0.018 & 0.016 & 1.14 & 0.253 & -0.013 & 0.049 \\
SRI & 0.001 & 0.004 & 0.20 & 0.842 & -0.006 & 0.008 \\
LEV & 0.005 & 0.002 & 2.21 & $0.027 * *$ & 0.000 & 0.009 \\
BETA & -0.000 & 0.000 & -0.97 & 0.332 & -0.000 & 0.000 \\
SIZE & 0.004 & 0.001 & 2.70 & $0.001 * * *$ & 0.001 & 0.006 \\
MB & 0.000 & 0.000 & 1.09 & 0.278 & -0.00 & 0.002 \\
CONSTANT & 0.068 & 0.009 & 7.07 & $0.000 * * *$ & 0.049 & 0.086 \\
\hline
\end{tabular}

s.e., standard error; IR_SCORE, integrated reporting score; BRDSIZE, board size; INDEP independence of directors; SRI, sustainability reporting index; LEV, financial leverage; BETA market beta; SIZE, firm size; MB, market-to-book value.

Note: Robust standard error estimates were obtained from STATA in order to deal with heteroscedasticity and autocorrelation.

**, significant at the 0.05 level (two tailed); ***, significant at the 0.001 level (two tailed).

TABLE 6: Regression results: Cost of equity (before and after integrated reporting framework).

\begin{tabular}{lcccccc}
\hline Variables & Coefficient & Robust s.e. & $\mathbf{Z}$ & $\boldsymbol{p}$ & $\mathbf{9 5 \%}$ conf. & Interval \\
\hline BAIR & -0.0307 & 0.0578 & -5.31 & $0.000^{* * *}$ & -0.0420204 & -0.194 \\
BRDSIZE & 0.0031 & 0.002 & 0.19 & 0.846 & -0.0028425 & 0.034 \\
INDEP & 0.026 & 0.021 & 1.24 & 0.213 & -0.0152726 & 0.068 \\
SRI & -0.009 & 0.005 & -1.76 & $0.07 *$ & -0.010704 & -0.203 \\
LEV & -0.017 & 0.002 & -8.08 & $0.000 * * *$ & -0.0235944 & 0.001 \\
BETA & 0.07 & 0.005 & 1.4 & 0.161 & -0.0031566 & -0.019 \\
SIZE & 0.01 & 0.002 & 0.68 & 0.498 & -0.0032911 & 0.0067 \\
MB & -0.012 & 0.004 & -2.98 & $0.003 * *$ & -0.0200427 & -0.004 \\
CONSTANT & 0.118 & 0.038 & 3.07 & $0.002 * *$ & 0.0428087 & 0.0193
\end{tabular}

s.e., standard error, BAIR for before and after IR framework, IR_SCORE, integrated reporting score; BRDSIZE, board size; INDEP, independence of directors; SRI, sustainability reporting index; LEV, financial leverage; BETA, market beta; SIZE, firm size; MB, market-to-book value. Note: Robust standard error estimates were obtained from STATA in order to deal with heteroscedasticity and autocorrelation.

*, Significant at the 0.1 level (two tailed); **, significant at the 0.05 level (two tailed); $* * *$, Significant at the 0.001 level (two tailed).
(Flower 2015). LEV $(p=0.01)$ and $\operatorname{MB}(p=0.05)$ also show an inverse significant relationship with the cost of equity.

Table 7 above presents fixed effects regression analysis of the relationship between analysts' forecast error and the independent variables. Similar to the study on the effect of voluntary disclosures on FCERROR by Dhaliwal et al. (2012), there is a significant $(p=0.1)$ inverse relationship between the IR score and forecast errors and negative coefficient of -0.956 . The results confirm the findings of related previous studies (Dhaliwal et al. 2012; Flores et al. 2019; Vitolla et al. 2019). Despitea limited number of observations owing to unavailability of data, the results indicate that IR may assist in minimising analysts forecast errors. The variables that significantly influence FCERROR include company board size (BRDSIZE, $p=0.06$ ) and market-to-book value ratio (MB, $p=0.06)$.

\section{Conclusion}

This study investigated the effects of IR on the COE as well as FCERROR. The research was motivated by the prevalent discourse on whether or not IR offers any benefits to the reporting entity. In this regard, we examined whether firms with higher IR scores experienced a reduction in the COE. Secondly, an analysis of cost of equity was made for before and after IR framework. Furthermore, the study investigated if higher IR scores lead to low FCERROR. To this end, we prepared three regression analyses in order to observe interplay between dependent variables (COE and FCERROR) and IR scores.

After controlling for other variables that could influence the outcome, the study found a significant negative relationship between higher IR scores and cost of equity. Notably, results were more pronounced for before and after IR framework cohort. The more pronounced results could be attributed to more observations and higher quality of integrated reports. We also noted that firms with higher scores generally are bigger (SIZE) than those with lower IR scores. The quality of IR could be largely influenced by the size of the firm. Similarly, the study found significant relationship between higher IR scores and FCERROR. Despite limited data for

TABLE 7: Regression results: Analysts' forecast error.

\begin{tabular}{lcccccc}
\hline Variables & Coefficient & Robust s.e. & $\mathbf{Z}$ & $\boldsymbol{p}$ & $\mathbf{9 5 \%}$ conf. & Interval \\
\hline IR_SCORE & -0.956 & 0.484 & -1.98 & $0.07 *$ & -2.002 & 0.089 \\
BRDDSIZE & -4.693 & 2.318 & -2.02 & $0.064 *$ & -9.701 & 0.314 \\
INDEP & 11.43 & 15.945 & 0.72 & 0.486 & -23.011 & 45.885 \\
SRI & 3.891 & 2.494 & 1.56 & 0.143 & -1.498 & 9.281 \\
LEV & 8.017 & 5.267 & 1.52 & 0.152 & -3.361 & 19.396 \\
BETA & 0.032 & 0.039 & 0.83 & 0.406 & -0.044 & 0.109 \\
SIZE & -2.581 & 1.542 & -1.67 & 0.118 & -5.914 & 0.751 \\
MB & -8.119 & 3.944 & -2.06 & $0.06 *$ & -16.641 & 0.402 \\
VOL & 8.465 & 13.918 & 0.61 & 0.553 & -21.602 & 38.533 \\
CONSTANT & 97.46 & 47.075 & 2.07 & $0.059 *$ & -4.235 & 199.1637 \\
\hline
\end{tabular}

s.e. standard error, IR_SCORE, integrated reporting score; BRDSIZE, board size; INDEP, independence of directors; SRI, sustainability reporting index; LEV, financial leverage; BETA, market beta; SIZE, firm size; MB, market-to-book value; VOL, volatility of earnings.

Note: Robust standard error estimates were obtained from STATA in order to deal with heteroscedasticity and autocorrelation.

*, Significant at the 0.1 level (two tailed). 
probing analysts forecast errors, the results still confirm the possible positive contribution of IR towards minimising analysts forecast errors. Similar to previous literature by Zhou et al. (2017), Vena, Sciascia and Cortesi (2020) and Vitolla et al. (2020b), results of this study confirm that IR may lead to reduction of COE and FCERROR.

The study was limited to only mining firms listed on JSE. Some of the other limitations included unavailability of metrics on databases, particularly, data for analysts' forecasts errors. Future studies could cover a larger sample in order to produce more compelling evidence. Furthermore, the scope of measurement of markets rewards could be larger. Other economic outcomes to be investigated include financial performance, accessibility to capital and firm value. Moreover, given an increase in the number of jurisdictions that have made IR mandatory, it would be interesting to investigate whether its purported benefits are prevalent in other settings. Incorporating questionnaires and interviews with accountants, executives, investors and some shareholders to corroborate the evidence would also provide a broader perspective on the benefits of IR.

\section{Implications for policy makers and researchers}

Albeit a small sample, results of the study provide support for IR. Studies of this nature are relevant, particularly, in the corporate reporting space where there are ongoing discourses about the benefits of IR. Integrated reporting framework provides a paradigm shift in reporting, especially the integrated thinking phenomenon and connectedness of both financial and non-financial reporting sections. Policy makers could be influenced by more empirical evidence to support or reject financial gains of adopting IR. This is particularly true in settings where IR is not mandatory. In terms of research, findings may contribute to the existing discourse of firm-based benefits associated with IR.

\section{Acknowledgements}

We are grateful for reviews and constructive feedback from the editorial team.

\section{Competing interests}

The authors declare that they have no financial or personal relationships that may have inappropriately influenced them in writing this article.

\section{Authors' contributions}

B.N. did literature review, research methodology, data collection, data analysis and interpretation of results. M.S. assisted with the supervision and final layout of the manuscript.

\section{Ethical considerations}

This article followed all ethical standards for research without direct contact with human or animal subjects.

\section{Funding information}

This research received no specific grant from any funding agency in the public, commercial or not-for-profit sectors.

\section{Data availability}

The data were collected from firms' websites, Bloomberg database and Johannesburg Stock Exchange website. A spreadsheet was then prepared to capture and sort data, after which it was analysed through the use of STATA 15.

\section{Disclaimer}

The views and opinions expressed in this article are those of the authors and do not necessarily reflect the official policy or position of any affiliated agency of the author.

\section{References}

Adhariani, D. \& De Villiers, C., 2019, 'Integrated reporting: Perspectives of corporate report preparers and other stakeholders', Sustainability Accounting, Management And Policy Journal 10(1), 126-156. https://doi.org/10.1108/ SAMPJ-02-2018-0043

Alabdullah, T.T.Y., Nor, M.I. \& Ries, E., 2018, 'The determination of firm performance in emerging nations: Do board size and firm size matter', Management 5(2), 57-66. https://doi.org/10.9756/IAJAFM/V5I2/1810017

Baboukardos, D. \& Rimmel, G., 2016, 'Value relevance of accounting information under an integrated reporting approach: A research note', Journal of Accounting and Public Policy 35(4), 437-452. https://doi.org/10.1016/j.jaccpubpol.2016. 04.004

Bakker, R., Georgakopoulos, G., Sotiropoulou, V.-A. \& Tountas, K.S., 2020, 'The impact of integrated reporting on analysts' forecasts', International Journal of Economics and Finance 12(1), 76-89. https://doi.org/10.5539/ijef.v12n1p76

Barth, M.E., Cahan, S.F., Chen, L. \& Venter, E.R., 2017, 'The economic consequences associated with integrated report quality: Capital market and real effects', Accounting, Organizations And Society 62, 43-64. https://doi.org/10.1016/j. aos.2017.08.005

Barth, M.E., Kasznik, R. \& Mcnichols, M.F., 2001, 'Analyst coverage and intangible assets', Journal of Accounting Research 39(1), 1-34. https://doi.org/10.1111/1475 679X.00001

Bernardi, C. \& Stark, A.W., 2018, 'Environmental, social and governance disclosure, integrated reporting, and the accuracy of analyst forecasts', The British Accounting Review 50(1), 16-31. https://doi.org/10.1016/j.bar.2016.10.001

Bissessur, S.W. \& Veenman, D., 2016, 'Analyst information precision and small earnings surprises', Review of Accounting Studies 21, 1327-1360. https://doi.org/10.1007/ s11142-016-9370-2

Botosan, C.A., 1997, 'Disclosure level and the cost of equity capital', Accounting Review 323-349.

Botosan, C.A. \& Plumlee, M.A., 2005, 'Assessing alternative proxies for the expected risk premium', The Accounting Review 80(1), 21-53. https://doi.org/10.2308/ accr.2005.80.1.21

Bradshaw, M.T., Miller, G.S. \& Serafeim, G., 2009, Accounting method heterogeneity and analysts' forecasts, Unpublished Paper, University of Chicago, University of Michigan, and Harvard University.

Chang, K., Pei, P., Zhang, C. \& Wu, X., 2017, 'Exploring the price dynamics of Co emissions allowances in China's emissions trading scheme pilots', Energy Economics 67, 213-223. https://doi.org/10.1016/j.eneco.2017.07.006

Ciftci, I., Tatoglu, E., Wood, G., Demirbag, M. \& Zaim, S., 2019, 'Corporate governance and firm performance in emerging markets: Evidence from Turkey', International Business Review 28(1), 90-103. https://doi.org/10.1016/j. ibusrev.2018.08.004

Claus, J. \& Thomas, J., 2001, 'Equity premia as low as three percent? Evidence from analysts' earnings forecasts for domestic and international stock markets', The Journal Of Finance 56(5), 1629-1666. https://doi.org/10.1111/0022The Journal
1082.00384

Conway, E., 2019, 'Quantitative impacts of mandatory integrated reporting', Journal of Financial Reporting and Accounting 17(4), 604-634. https://doi.org/10.1108/ JFRA-08-2018-0066

Cosma, S., Soana, M.G. \& Venturelli, A., 2018, 'Does the market reward integrated report quality?', African Journal of Business Management 12(4), 78-91. https:// doi.org/10.5897/AJBM2017.8469

Cox, S. \& Britten, J., 2019, 'The Fama-French five-factor model: Evidence from the Johannesburg Stock Exchange', Investment Analysts Journal 48(3), 240-261. https://doi.org/10.1080/10293523.2019.1647982 
Dhaliwal, D.S., Li, O.Z., Tsang, A. \& Yang, Y.G., 2011, 'Voluntary nonfinancial disclosure and the cost of equity capital: The initiation of corporate social responsibility reporting', The Accounting Review 86(1), 59-100. https://doi.org/10.2308/ reporting, The

Dhaliwal, D.S., Radhakrishnan, S., Tsang, A. \& Yang, Y.G., 2012, 'Nonfinancial disclosure and analyst forecast accuracy: International evidence on corporate social responsibility disclosure', The Accounting Review 87(3), 723-759. https://doi. responsibility disclosure,
org/10.2308/accr-10218

Diamond, D.W. \& Verrecchia, R.E., 1991, 'Disclosure, liquidity, and the cost of capital', The Journalof Finance 46(4), 1325-1359. https://doi.org/10.1111/j.1540-6261.1991. The Journa
tb04620.x

Dichev, I.D. \& Tang, V.W., 2009, 'Earnings volatility and earnings predictability', Journa of Accounting and Economics 47(1-2), 160-181. https://doi.org/10.1016/j. of Accounting and

Dirman, A., 2019, 'Analysis of good corporate governance and corporate social responsibility disclosure on cost of equity capital in listing CGPI and BEI 2013-2017', Research Journal of Finance and Accounting 10, 1-10.

Dube, V., 2017, The association between integrated reporting and company financial performance: A graphical time-series approach, Master of Business Administration Masters, Gordon Institute of Business Science - University of Pretoria.

Dzingai, I. \& Fakoya, M.B., 2017, 'Effect of corporate governance structure on the financial performance of Johannesburg Stock Exchange (JSE)-listed mining firms', Sustainability 9(6), 867. https://doi.org/10.3390/su9060867

Easton, A.J., Domachowske, J.B. \& Rosenberg, H.F., 2004, 'Animal pneumoviruses: Molecular genetics and pathogenesis', Clinical Microbiology Reviews 17(2), 390-412. https://doi.org/10.1128/CMR.17.2.390-412.2004

El Ghoul, S., Guedhami, O., Kwok, C.C. \& Mishra, D.R., 2011, 'Does corporate social responsibility affect the cost of capital?', Journal Of Banking \& Finance 35(9), 2388-2406. https://doi.org/10.1016/j.jbankfin.2011.02.007

Ellis, J.A., Fee, C.E. \& Thomas, S.E., 2012, 'Proprietary costs and the disclosure of information about customers', Journal of Accounting Research 50(3), 685-727. https://doi.org/10.1111/j.1475-679X.2012.00441.x

Eriandani, R., Narsa, I. \& Irwanto, A., 2019, 'Environmental risk disclosure and cost of equity', Polish Journal of Management Studies 19(2), 123-131. https://doi. org/10.17512/pjms.2019.19.2.10

Fama, E.F. \& French, K.R., 1993, 'Common risk factors in the returns on stocks and bonds', Journal of Economics 33(1), 3-56. https://doi.org/10.1016/0304405X(93)90023-5

Flores, E., Fasan, M., Mendes-Da-Silva, W. \& Sampaio, J.O., 2019, 'Integrated reporting and capital markets in an international setting: The role of financial analysts' Business Strategy and the Environment 28(7), 1465-1480. https://doi. org/10.1002/bse. 2378

Flower, J., 2015, 'The international integrated reporting council: A story of failure', Critical Perspectives on Accounting 27, 1-17. https://doi.org/10.1016/j.cpa. 2014.07.002

FTSE, J., 2019, Sriindex, viewed 15 January 2021, from https://www.Jse.Co.Za/ Services/Indices/Ftsejse-Responsible-Investment-Index-Series.

García-Sánchez, I.M. \& Noguera-Gámez, L., 2017, 'Integrated reporting and stakeholder engagement: The effect on information asymmetry', Corporate Socia Responsibility and Environmental Management 24(5), 395-413. https://doi. org/10.1002/csr.1415

Gebhardt, W.R., Lee, C.M. \& Swaminathan, B., 2001, 'Toward an implied cost of capital', Journal of Accounting Research 39(1), 135-176. https://doi. org/10.1111/1475-679X.00007

Guidry, R.P. \& Patten, D.M., 2012, 'Voluntary disclosure theory and financial control variables: An assessment of recent environmental disclosure research', Accounting Forum 36(1), 81-90.

Guru, P., 2019, Problems faced during statistical analysis using panel data with stata viewed 16 January 2020, from https://www.Projectguru.In/Solutions-ProblemsPanel-Data-Analysis.

Hail, L., 2002, 'The impact of voluntary corporate disclosures on the ex-ante cost of capital for Swiss firms', European Accounting Review 11(4), 741-773. https://doi. org/10.1080/0963818022000001109

Hausman, J.A. \& Taylor, W.E., 1981, 'Panel data and unobservable individual effects' Econometrica: Journal of the Econometric Society 49(6), 1377-1398. https://doi. org/10.2307/1911406

IIRC, 2013, The international <IR> framework, viewed 05 April 2019, from http://www. Theiirc.Org/International-Irframework/.

IoDSA, 2020, King IV report on corporate governance, viewed 15 October 2020, from https://www.lodsa.Co.Za/Page/Downloadkingivapp.

Jensen, M.C. \& Meckling, W.H., 1976, 'Theory of the firm: Managerial behavior, agency costs and ownership structure', Journal of Financial Economics 3(4), 305-360. https://doi.org/10.1016/0304-405X(76)90026-X

Johnson, R., 2020, 'The link between environmental, social and corporate governance disclosure and the cost of capital in South Africa', Journal of Economic and Financial Sciences 13(1), 12. https://doi.org/10.4102/jef.v13i1.543

JSE, 2015, Johannessburg Stock Exchange 'The JSE and sustainability', viewed 06 April 2019, from https://www.Jse.Co.Za/About/Sustainability.

JSE, 2021, Johannessburg Stock Exchange, viewed 09 March 2021, from https://www. Jse.Co.Za/News/Press-Releases/Jse-Delivers-Business-Resilience-And-FlexibilityUniquely-Challenging-Year.
Karp, A. \& Van Vuuren, G., 2017, 'The capital asset pricing model and Fama-French Three factor model in an emerging market environment', International Business \& Economics Research Journal (Iber) 16(4), 231-256. https://doi.org/10.19030/iber. Economics Resec

Khlif, H., Samaha, K. \& Soliman, M., 2019, 'Internal control quality, voluntary disclosure, and cost of equity capital: The case of an unregulated market', Internationa Journal of Auditing 23(1), 144-160. https://doi.org/10.1111/ijau.12151

Krechovská, M. \& Procházková, P.T., 2014, 'Sustainability and its integration into corporate governance focusing on corporate performance management and reporting', Procedia Engineering 69, 1144-1151. https://doi.org/10.1016/j. reporting,', Procedia
proeng.2014.03.103

Lambert, R., Leuz, C. \& Verrecchia, R.E., 2007, 'Accounting information, disclosure and the cost of capital', Journal of Accounting Research 45(2), 385-420. https:// doi.org/10.1111/j.1475-679X.2007.00238.x

Lee, K.-W. \& Yeo, G.H.-H., 2016, 'The association between integrated reporting and firm valuation', Review of Quantitative Finance and Accounting 47, 1221-1250. https://doi.org/10.1007/s11156-015-0536-y

Lehavy, R., Li, F. \& Merkley, K., 2011, 'The effect of annual report readability on analyst following and the properties of their earnings forecasts', The Accounting Review 86(3), 1087-1115. https://doi.org/10.2308/accr.00000043

Mazzotta, R. \& Veltri, S., 2014, 'The relationship between corporate governance and the cost of equity capital. Evidence from the Italian Stock Exchange', Journal of Management \& Governance 18, 419-448. https://doi.org/10.1007/s10997-012Manag

Merendino, A. \& Melville, R., 2019, 'The board of directors and firm performance: Empirical evidence from listed companies', Corporate Governance: The International Journal of Business in Society 19(3), 508-551. https://doi. org/10.1108/CG-06-2018-0211

MineralsSA, 2018, Mining in SA, viewed 21 April 2019, from https://www. Mineralscouncil.Org.Za/Sa-Mining.

Moyo, V. \& Mache, F., 2018, 'Inferring the cost of equity: Does the CAPM consistently outperform the income and multiples valuation models?', Journal of Applied Business Research (JABR) 34(3), 519-532. https://doi.org/10.19030/jabr. v34i3.10174

Mulyati, Y., 2017, 'The influence of voluntary disclosure, stock beta, and firms size on cost of equity capital', Jurnal Keuangan Dan Perbankan 21(3), 387-396. https:// doi.org/10.26905/jkdp.v21i3.1506

Ohlson, J.A. \& Juettner-Nauroth, B.E., 2005, 'Expected EPS and EPS growth as determinants of value', Review of Accounting Studies 10, 349-365. https://doi. org/10.1007/s11142-005-1535-3

Panda, B. \& Leepsa, N., 2017, 'Agency theory: Review of theory and evidence on problems and perspectives', Indian Journal of Corporate Governance 10(1), 74-95. https://doi.org/10.1177/0974686217701467

Peters, G.F. \& Romi, A.M., 2014, 'Does the voluntary adoption of corporate governance mechanisms improve environmental risk disclosures? Evidence from greenhouse gas emission accounting', Journal of Business Ethics 125, 637-666. https://doi. org/10.1007/s10551-013-1886-9

Petrova, E., Georgakopoulos, G., Sotiropoulos, I. \& Vasileiou, K.Z., 2012, 'Relationship between cost of equity capital and voluntary corporate disclosures', International Journal of Economics and Finance 4(3), 83-96. https://doi.org/10.5539/ijef. v4n3p83

Pistoni, A., Songini, L. \& Bavagnoli, F., 2018, 'Integrated reporting quality: An empirical analysis', Corporate Social Responsibility and Environmental Management 25(4), 489-507. https://doi.org/10.1002/csr.1474

Poshakwale, S. \& Courtis, J.K., 2005, 'Disclosure level and cost of equity capital: Evidence from the banking industry', Managerial and Decision Economics 26(7), 431-444. https://doi.org/10.1002/mde.1256

Richardson, A.J. \& Welker, M., 2001, 'Social disclosure, financial disclosure and the cost of equity capital', Accounting, Organizations and Society 26(7-8), 597-616. https://doi.org/10.1016/S0361-3682(01)00025-3

Ross, S.A., 1973, 'The economic theory of agency: The principal's problem', The American Economic Review 63, 134-139.

Serafeim, G., 2015, 'Integrated reporting and investor clientele', Journal of Applied Corporate Finance 27(2), 34-51. https://doi.org/10.1111/jacf.12116

Shapiro, S.P., 2005, 'Agency theory', Annual Review of Sociology 31, 263-284. https:// doi.org/10.1146/annurev.soc.31.041304.122159

Sharpe, W.F., 1964, 'Capital asset prices: A theory of market equilibrium under conditions of risk', The Journal of Finance 19(3), 425-442. https://doi. org/10.1111/j.1540-6261.1964.tb02865.x

Suto, M. \& Takehara, H., 2018, 'Corporate social responsibility awareness and practices of Japanese corporations', in Corporate social responsibility and corporate finance in Japan, Springer.

Urquiza, F.B., Navarro, M.C.A., Trombetta, M. \& Lara, J.M.G., 2010, 'Disclosure theories and disclosure measures', Spanish Journal of Finance and Accounting/Revisto Española De Financiación Y Contabilidad 39(147), 393-420. https://doi.org/10.10 80/02102412.2010.10779686

Vena, L., Sciascia, S. \& Cortesi, A., 2020, 'Integrated reporting and cost of capital: The moderating role of cultural dimensions', Journal of International Financial Management \& Accounting 31(2), 191-214. https://doi.org/10.1111/ jifm.12113

Verrecchia, R.E., 2001, 'Essays on disclosure', Journal of Accounting and Economics 32(1-3), 97-180. https://doi.org/10.1016/S0165-4101(01)00025-8 
Vitolla, F., Raimo, N. \& Rubino, M., 2020a, 'Board characteristics and integrated reporting quality: An agency theory perspective', Corporate Social Responsibility and Environmental Management 27(2), 1152-1163, https://doi.org/10.1002/ csr.1879

Vitolla, F., Salvi, A., Raimo, N., Petruzzella, F. \& Rubino, M., 2019, 'The impact on the cost of equity capital in the effects of integrated reporting quality', Business Strategy and the Environment 29(2), 519-529. https://doi.org/10.1002/ bse. 2384
Vitolla, F., Salvi, A., Raimo, N., Petruzzella, F. \& Rubino, M., 2020b, 'The impact on the cost of equity capital in the effects of integrated reporting quality', Business Cost of equit and the Environment 29(2), 519-529. https://doi.org/10.1002/bse.2384
Strateg

Ward, M. \& Muller, C., 2012, 'Empirical testing of the CAPM on the JSE', Investment Analysts Journal 41(76), 1-12. https://doi.org/10.1080/10293523.2012.11082546

Zhou, S., Simnett, R. \& Green, W., 2017, 'Does integrated reporting matter to the capital market?', Abacus 53(1), 94-132. https://doi.org/10.1111/abac.12104 
Appendix 1: The coding framework.

\begin{tabular}{|c|c|}
\hline Dimensions & Components \\
\hline \multirow{5}{*}{$\begin{array}{l}\text { 1. Organisational overview } \\
\text { and external environment }\end{array}$} & 1.1 Mission and Vision \\
\hline & 1.2 Culture, ethics and value \\
\hline & $\begin{array}{l}\text { 1.3 Activities, markets, competition and market } \\
\text { position }\end{array}$ \\
\hline & 1.4 Summary statistics \\
\hline & 1.5 Significant factors affecting operations \\
\hline \multirow[t]{5}{*}{ 2. Governance } & 2.1 Leadership structure \\
\hline & 2.2 Processes for decision-making \\
\hline & 2.3 Reflection on strategic decisions \\
\hline & $\begin{array}{l}\text { 2.4 Reflection on organisation culture, ethics and } \\
\text { values }\end{array}$ \\
\hline & 2.5 Strategic plans for innovation \\
\hline \multirow[t]{10}{*}{ 3. Business Model } & 3.1 Description of business model \\
\hline & $\begin{array}{l}\text { 3.2 Description of activities, inputs, outputs and } \\
\text { outcome }\end{array}$ \\
\hline & 3.3 Graphical presentation of business model \\
\hline & 3.4 Reflection of inputs in relation to capitals \\
\hline & $\begin{array}{l}\text { 3.5 How the entity differentiates itself in the market } \\
\text { place }\end{array}$ \\
\hline & 3.6 How the model adapts to changes in economy \\
\hline & 3.7 Identification of key products and services \\
\hline & 3.8 Reflection on internal and external outcomes \\
\hline & 3.9 Effects of outcomes on capitals \\
\hline & 3.10 Both positive and negative outcomes \\
\hline \multirow[t]{3}{*}{ 4. Risks and opportunities } & 4.1 Key risks and opportunities specific to the firm \\
\hline & 4.2 Sources of risk and opportunities \\
\hline & $\begin{array}{l}\text { 4.3 Plans to mitigate risks and capitalise on } \\
\text { opportunities }\end{array}$ \\
\hline \multirow[t]{5}{*}{$\begin{array}{l}\text { 5. Strategy and resource } \\
\text { allocation }\end{array}$} & $\begin{array}{l}5.1 \text { Reflection on short-, medium- and long-terms } \\
\text { objectives }\end{array}$ \\
\hline & 5.2 Strategies in place to achieve objectives \\
\hline & 5.3 Resource allocation plans \\
\hline & 5.4 Control measures for the objectives \\
\hline & $\begin{array}{l}5.5 \text { Linkage between strategy and resource allocation } \\
\text { plans, and other content elements }\end{array}$ \\
\hline \multirow[t]{5}{*}{ 6. Performance } & $\begin{array}{l}\text { 6.1 Quantitative indicators with respect to targets and } \\
\text { risks and opportunities }\end{array}$ \\
\hline & 6.2 Positive and negative effects on capitals \\
\hline & 6.3 State of stakeholder relationship \\
\hline & $\begin{array}{l}\text { 6.4 Link between past, current and future } \\
\text { performance }\end{array}$ \\
\hline & 6.5 Financial analysis of effects on capitals \\
\hline \multirow[t]{5}{*}{ 7. Outlook } & 7.1 Expectations about the external environment \\
\hline & 7.2 The impact of changes on the firm \\
\hline & 7.3 Measures in place to respond to changes \\
\hline & $\begin{array}{l}\text { 7.4 Implications of external environment on financial } \\
\text { performance }\end{array}$ \\
\hline & 7.5 The availability of capitals and the firm uses \\
\hline
\end{tabular}

Source: Adapted (IIRC, 2013, The international $<\mid R>$ framework, viewed 05 April 2019, from http:// www.Theiirc.Org/International-Irframework/) 